\title{
PERANCANGAN PURWARUPA KOMIK INTERAKTIF SAFETY RIDING BERKONSEP DIGITAL STORYTELLING
}

\author{
Godham Eko Saputro ${ }^{1}$, Toto Haryadi ${ }^{2}$, Dzuha Hening Yanuarsari ${ }^{3}$ \\ ${ }^{1,2,3}$ Program Studi Desain Komunikasi Visual, \\ Fakultas IImu Komputer, Universitas Dian Nuswantoro \\ godham.eko@gmail.com ${ }^{1}$, haryadi.dinus@gmail.com², dzuhadkvdinus@yahoo.com ${ }^{3}$
}

\begin{abstract}
Abstrak
Di Indonesia khususnya kota besar, kecelakaan yang disebabkan kendaraan bermotor menjadi persoalan yang serius. Salah satunya disebabkan kurangnya pemahaman tentang safety riding. Berbagai upaya kampanye safety riding pun telah dilaksanakan oleh polisi lalu lintas melalui talkshow, siaran radio, serta media leaflet bagi masyarakat yang dilakukan berulangulang. Hal itu mendorong peneliti dalam upaya menemukan strategi baru, salah satunya memanfaatkan perkembangan teknologi yang sangat pesat guna mengembangkan media pendukung kampanye safety riding yang tidak hanya dapat menyampaikan pesan, tetapi juga disukai dan bersifat menghibur. Data diperoleh melalui wawancara, observasi, serta studi literatur sebagai sumber konten purwarupa komik interaktif. Melalui pendekatan digital storytelling dan model komunikasi SMCR serta mengacu pada Penelitian Pengembangan, konsep purwarupa komik interaktif bisa dijabarkan lebih detail serta dapat diimplementasikan dalam perangkat mobile khususnya tablet PC. Diharapkan purwarupa ini dapat dikembangkan lebih lanjut sehingga benar-benar dapat dipublish secara umum sebagai media pendukung kampanye safety riding.
\end{abstract}

Kata Kunci: komik, interaktif, safety riding, digital storytelling

\begin{abstract}
In Indonesia especially in big cities, the accident which caused by rider is still become serious issue. One factor which cause accident is the lack of knowledge about safety riding. A lot of efforts which have been carried by traffic policeman are talkshow, radio broadcast, and leaflet media for public society. On the other hand, it courage the researchers in effort to find new startegy, one of them is using the advance of technology to develop another media campaign which not only can deliver the messages, but also can entertain user. This research is an effort to find unconventional media for safety riding campaign. Data was obtained through interview, observation, and study of literature as sources of content for interactive comic. Through digital storytelling approach and communication model of SMCR and refers to Research and Development, the concept prototype of interactive comic can be described more detail and also can be implemented in mobile device especially tablet PCs. The prototype is expected can be develop further so it really can be published as supported media for safety riding campaign.
\end{abstract}

Keywords: comic, interactive, safety riding, digital storytelling 


\section{PENDAHULUAN}

\subsection{Latar Belakang}

Kecelakaan lalu lintas yang terjadi di Indonesia begitu memprihatinkan. Kasatlantas Polrestabes Semarang, AKBP Windro Akbar melalui sindonews.com mengemukakan bahwa pengendara motor usia 16-30 tahun menjadi penyumbang kecelakaan lalu lintas terbesar di jalan raya akibat faktor human error, khususnya ugal-ugalan dan mengantuk. Kebiasaan berkendara yang kurang terkontrol mendorong terciptanya kebiasaan berkendara yang tidak baik dan benar hingga masa mendatang, sebagaimana dijelaskan Selligman melalui Sitompul (2009) populer dengan istilah Learned Helplessness. Tingginya angka korban tewas akibat kecelakaan lalu lintas di kota Semarang yang mencapai 164 orang pada medio Januari - Oktober 2013 menunjukkan bahwa ini menjadi masalah serius yang perlu mendapat perhatian, khususnya dalam hal safety riding atau keamanan berkendara.

Safety riding menurut Pramitasari, Ratih, dkk (2013), adalah upaya untuk mengurangi angka kecelakaan lalu lintas serta dampak yang ditimbulkannya dan perlu digalakkan, sebab safety riding fokus pada upaya meningkatkan kesadaran pengendara atas segala kemungkinan yang bisa terjadi untuk mewujudkan keselamatan (Ariwibowo, 2013). Kampanye safety riding sudah pernah dilakukan oleh pihak Polantas kota Semarang melalui seminar yang dilakukan di beberapa Sekolah Menengah Atas. Kampanye tersebut belum bisa disosialisasikan secara merata, sehingga diperlukan strategi beserta media yang kreatif dan komunikatif.

Pada tahun 2009, peneliti pernah mengembangkan buku panduan aman berkendara sepeda motor sebagai penunjang kampanye safety riding. Kelemahan media ini yaitu informasi yang disampaikan bersifat satu arah. Media lain yang pernah dikembangkan peneliti yakni game simulasi safety riding pada tahun 2013. Meskipun merupakan terobosan baru, game terlalu teknis dan mengedepankan fun sehingga informasi utamanya menjadi terabaikan.

Salah satu media kreatif dan komunikatif yang berpotensi mendukung kampanye safety riding yaitu komik. Komik menurut McCloud (2008) adalah media penyampaian pesan berisi kumpulan gambar serta lambang lain yang ditata bersebelahan dalam urutan tertentu. Informasi ditampilkan dalam bentuk verbal dan visual, yang berhubungan dengan indera penglihatan. Di sisi lain, mengutip pernyataan Parmikoadi, D., M., dkk. (2013), bahwa manusia memiliki kemampuan menyerap informasi dengan persentase terbesar yaitu melalui indera mata (83\%), diikuti telinga (11\%), hidung $(3,5 \%)$, peraba $(1,5 \%)$, serta perasa $1 \%$. Hal ini menunjukkan komik berpotensi menjadi media kampanye safety riding. Namun, sama halnya buku, komik bersifat satu arah sehingga belum menciptakan keaktifan pembaca dalam memahami informasi seputar safety riding. Opsi solusi dari permasalahan di atas salah satunya yakni mengkombinasikan komik dengan konsep multimedia interaktif yang bisa menggabungkan elemen teks, gambar, audio, video, atau animasi dalam satu bentuk. Komik interaktif memiliki kelebihan dibanding buku dan game sebagai media kampanye terdahulu. Komik interaktif mampu menyampaikan informasi secara ringkas 
dan jelas dibanding buku, serta bersifat lebih serius dibanding game yang mengutamakan aspek fun. Selain itu, semakin maraknya perangkat mobile dalam bentuk smartphone maupun tablet PC (khususnya OS andriod) bisa dimanfaatkan untuk desain purwarupa komik interaktif.

Berdasarkan pertimbangan di atas, penelitian purwarupa komik interaktif diadaptasi untuk kampanye safety riding dalam konsep baru yang melibatkan indera penglihatan dan peraba, sehingga informasi yang disampaikan lebih maksimal serta diminati khalayak khususnya remaja. Hasil penelitian ini diharapkan dapat membantu instansi terkait dalam mengkampanyekan safety riding sehingga menumbuhkan kesadaran berkendara yang baik dan benar.

\subsection{Safety Riding}

Safety riding menurut Boykhe (2008) dalam Yamaha Safety Riding Science (YSRS) merupakan tata cara berkendara roda dua yang aman dan nyaman bagi pribadi maupun semua pengguna jalan. Semakin banyaknya volume kendaraan serta angka kecelakaan lalu lintas yang dialami pengendara sepeda motor mendorong perlu dilakukannya kampanye safety riding, khususnya bagi remaja. Berkendara tidak sekedar bisa mengendarai roda dua, tetapi juga memahami aturan-aturan yang berlaku. Pentingnya kampanye safety riding menurut CARRS-Q dilatarbelakangi oleh alasan risiko terjadi kecelakaan yang lebih besar pada sepeda motor dibanding mobil, meliputi: 1) kurangnya perlindungan akibat akselerasi motor yang tinggi; 2) jarak penglihatan, sepeda motor rentan tidak terlihat pengendara mobil; 3) kurang pengalaman bagi pengendara baru; serta 4)tingkat kestabilan rendah khususnya dalam manuver dan rem.

\subsection{Komik}

Menurut KBBI, komik berarti cerita bergambar yang dimuat dalam majalah, surat kabar, atau dalam bentuk buku. Sejarah komik diawali dari lukisan prasejarah di dinding gua sebagai penyajian unsur estetis dan pengganti kata-kata. Seiring waktu komik tidak hanya berfungsi sebagai hiburan, tetapi juga menjadi sarana komunikasi pembelajaran dan media sosialisasi.

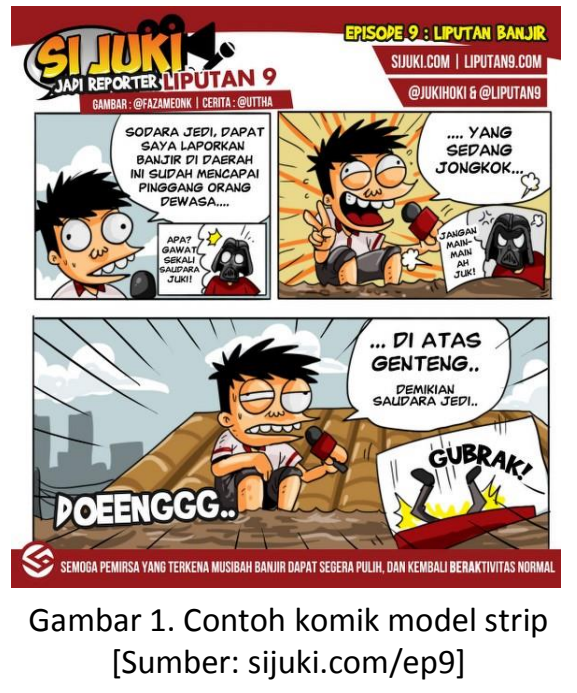


Melalui jalan cerita dan sajian yang berurutan, menurut Danesi (2010), komik mudah ditelaah maknanya satu persatu, menambah daya imajinasi, dan menanamkan kesan yang kuat dalam benak pembaca.

\subsection{Media Interaktif}

Pembahasan tentang media interaktif berkaitan dengan multimedia. Multimedia menurut Binanto (2010), merupakan gabungan dari elemen teks, seni, suara, gambar, animasi dan video yang dimanipulasi secara digital, ditayangkan melalui komputer, serta bisa dikontrol secara interaktif. Berdasarkan sifat interaksi antara produk dengan pengguna, multimedia dibagi menjadi tiga jenis, yaitu: 1) multimedia interaktif, pengguna bisa mengontrol elemen multimedia apapun yang ditampilkan kapanpun; 2) multimedia hiperaktif, terdapat banyak link yang menghubungkan elemen-elemen multimedia; serta 3) multimedia linear, pengguna tidak bisa berinteraksi dan hanya sebagai penonton.

Multimedia interaktif seperti dikutip dari England \& Finney (2011), merupakan integrasi media digital termasuk teks elektronik, grafis, animasi, dan suara ke dalam sebuah struktur lingkungan digital terkomputerisasi yang mengijinkan pengguna bisa berinteraksi dengan data sesuai keperluan. Menurut Laurillard dalam Burnett dkk, penggunaan multimedia interaktif yang ditujukan untuk pembelajaran perlu didasarkan pada karakteristik berikut: 1) diskursif, memungkinkan pengguna berpikir langkah demi langkah; 2) konten produk multimedia menyesuaikan pemahaman pengguna; 3) interaktif, pengguna harus mendapatkan umpan balik langsung terkait dengan produk; serta 4) reflektif, produk multimedia harus mendukung proses pembelajaran sesuai dengan tindakan umpan balik pengguna.

\section{METODE PENELITIAN}

Penelitian ini menggunakan metode deskriptif kualitatif, yakni data yang digunakan berupa data deskriptif baik dalam bentuk verbal maupun visual. Metode pengumpulan data dilakukan melalui wawancara, observasi, serta studi literatur. Wawancara dilakukan dengan pihak Kepolisian Lalu Lintas Kota Semarang di Kantor Polisi Sektor Semarang Barat. Observasi dilakukan dengan mengamati contoh pelanggaran, sedangkan studi literatur dilakukan dengan mencari referensi terkait tema safety riding dari buku atau media massa. Studi literatur juga dilakukan dengan mencari contoh produk digital storytelling yang memanfaatkan perangkat digital seperti komputer atau perangkat mobile. Data dari hasil kegiatan tersebut dijadikan sebagai landasan utama untuk mengembangkan purwarupa komik interaktif dengan konsep Digital Storytelling.

\subsection{Digital Storytelling (DST) dan Model Komunikasi SMCR}

Digital Storytelling (selanjutnya disebut DST) merupakan pengembangan dari storytelling yakni teknik bercerita secara digital. DeNatale (2008) menyebutkan bahwa DST merupakan wujud ekspresi modern dari kegiatan mendongeng secara langsung, dengan memanfaatkan layar komputer untuk berbagi pengetahuan, kebijaksanaan, dan nilai-nilai. Adaptasi DST dalam menyampaikan pengetahuan perlu memperhatikan bentuk relasi serta tools yang diperlukan. Interaksi yang terjadi dalam DST yaitu: 
collaborate, communicate, dan connect. Sedangkan tools yang menunjang kegiatan ini menurut Tolisano (2009) tersusun dari: choose/create media, storyline, serta project.
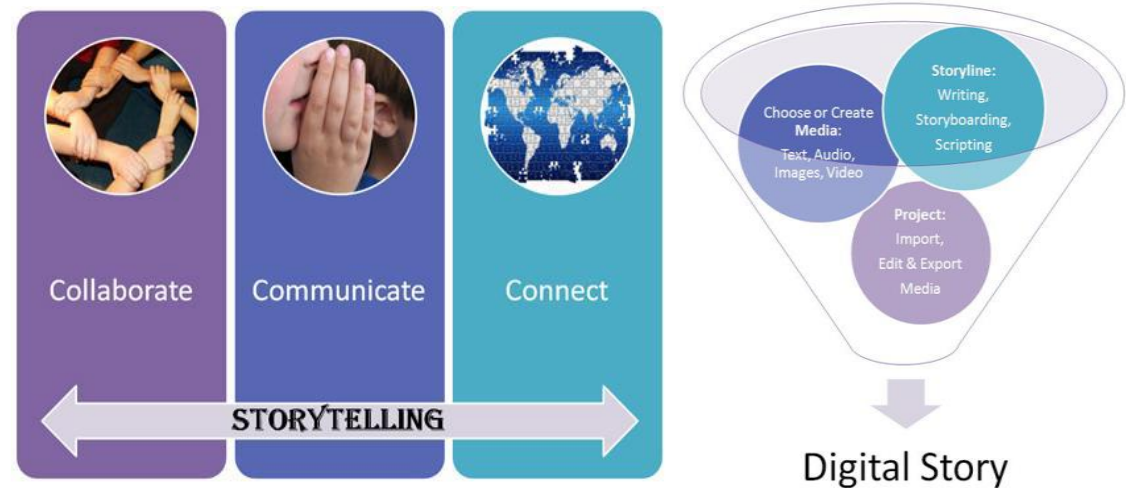

Gambar 2. Aspek Relasi pada DST (kiri) dan tools pembangun DST (kanan)

[Sumber: Tolisano, 2009: 7\&10]

Communicate pada Relasi di atas menjadi perhatian utama dalam membangun konsep DST yang mengacu pada pemilihan media meliputi: teks, gambar, audio, video, dan lain sebagainya untuk melahirkan konsep sarana penyampai pesan. Dalam hal ini, model komunikasi menjadi sangat penting guna mengakomodasi tujuan dari DST sesuai dengan media-media yang akan digunakan. Salah satu bentuk komunikasi yang relevan dengan konsep tersebut menurut Mulyana (2007) yakni model SMCR yang menggabungkan komunikasi publik, komunikasi antarpribadi dan tertulis, serta komunikasi bentuk lain.

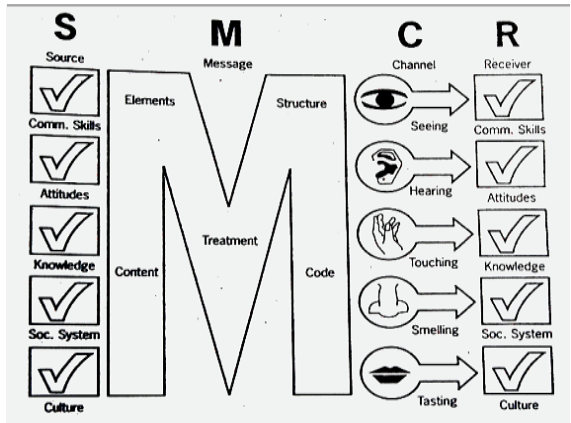

Gambar 3. Model komunikasi SMCR

[Sumber: Mulyana (2007:163)]

Bentuk komunikasi ini dibangun oleh empat elemen utama yang saling terkait, yakni: Source (sumber), Message (pesan), Channel (saluran), dan Receiver (penerima). Hubungan antara DST dengan model komunikasi ini terletak pada Channel, yang berarti mendayagunakan secara maksimal indera-indera yang dimiliki manusia.

\subsection{Penelitian Pengembangan (Research and Development)}

Penelitian Pengembangan merupakan penelitian yang fokus pada upaya mengembangkan produk yang bernilai guna khususnya dalam dunia akademik (Gay, 1990). Penelitian ini fokus pada pengembangan, yang secara spesifik pengembangan di sini yakni membuat pengetahuan yang sudah ada untuk digali lebih dalam dan lebih luas (Sugiyono, 2009), yang bertujuan agar kaidah atau ilmu pengetahuan, temuan 
teknologi, atau penemuan teknologi baru bisa lebih bermanfaat dan bisa diimplementasikan (Undang-Undang Republik Indonesia Nomor 18 Tahun 2002).

Penelitian Pengembangan secara garis besar terdiri atas dua tipe berdasarkan tujuannya (Richey dan Nelson, 2009), yakni: 1) jika ditujukan untuk mendapatkan gambaran proses pengembangan, maka terdapat penekanan pada aspek desain dan evaluasi produk; dan 2) jika ditujukan untuk mendapatkan gambaran prosedur desain dan evaluasi yang efektif, maka kajian terhadap pengembangan sebelumnya menjadi fokus utama. Untuk lebih jelasnya, proses Penelitian Pengembangan bisa dilihat melalui gambar berikut.

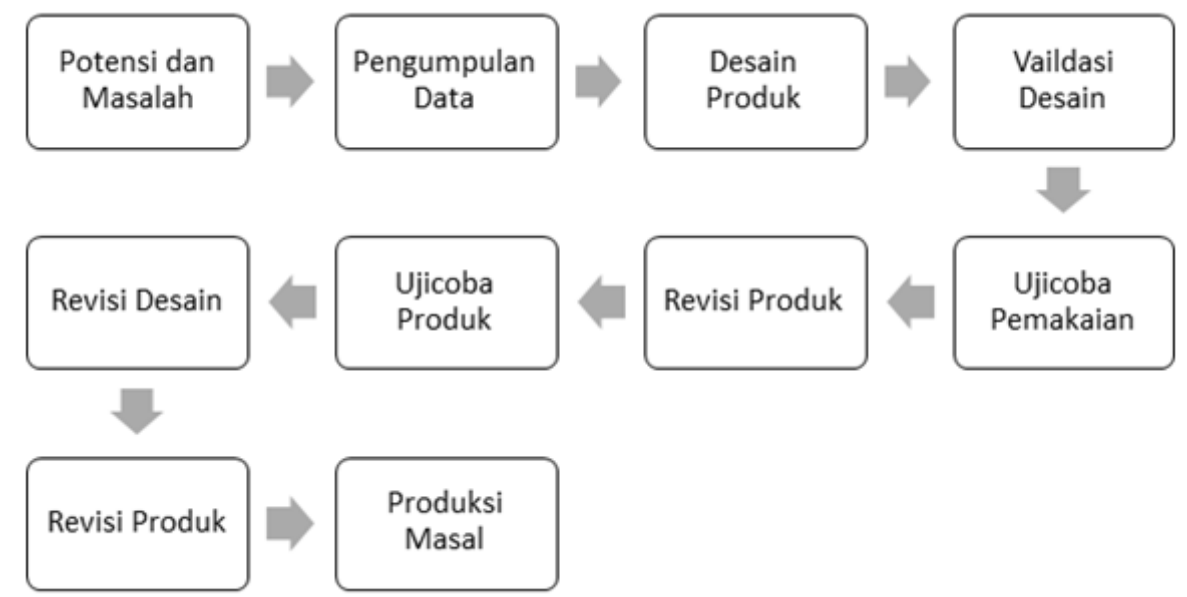

Gambar 4. Langkah Penelitian Pengembangan

[Sumber: Sugiyono, 2009]

\section{HASIL DAN PEMBAHASAN}

\subsection{Analisis Data}

Wawancara, observasi, serta studi literatur telah menghasilkan data sebagai referensi dalam membangun purwarupa komik interaktif. Berikut data yang telah diperoleh:

Tabel 1: Safety Riding: Sosialisasi dan Pelanggaran Pengendara

[Sumber: wawancara, observasi, studi literatur]

\begin{tabular}{|l|l|}
\hline \multicolumn{1}{|c|}{ Topik Safety Riding } & \multicolumn{1}{c|}{ Keterangan } \\
\hline Urgensi safety riding & $\begin{array}{l}\text { Sangat penting, sosialisasi terus berjalan hingga } \\
\text { saat ini, khususnya usia pelajar SMA-mahasiswa }\end{array}$ \\
\hline Bentuk tindakan safety riding & $\begin{array}{l}\text { Memakai helm, persiapan perlengkapan } \\
\text { berkendara, sabar }\end{array}$ \\
\hline Program Polantas & $\begin{array}{l}\text { Tetap mensosialisasikan safety riding melalui } \\
\text { kunjungan ke sekolah }\end{array}$ \\
\hline Media sosialisasi & $\begin{array}{l}\text { Talkshow langsung; media cetak: leaflet, spanduk, } \\
\text { surat kabar; media elektronik: radio dan internet } \\
\text { (media lain belum pernah digunakan) }\end{array}$ \\
\hline Jenis pelanggaran safety riding & $\begin{array}{l}\text { Tidak memakai helm, melanggar traffic light, } \\
\text { melanggar marka jalan / melewati trotoar, dsb }\end{array}$ \\
\hline Penyebab pelanggaran & $\begin{array}{l}\text { Terburu-buru, ketidaktahuan aturan lalu lintas, } \\
\text { egois dan tidak bisa mengontrol emosi }\end{array}$ \\
\hline
\end{tabular}


Tabel di atas menjelaskan poin-poin penting dalam safety riding. Sosialisasi yang dilakukan polantas bekerjasama dengan beberapa pihak yakni: stasiun radio, sekolah, serta masyarakat umum dilakukan secara konvensional melalui sarana diskusi, media cetak, serta media elektronik. Hal ini mendorong pihak polantas memberi kesempatan pihak lain salah satunya akademisi/dosen untuk bisa bekerjasama membangun media pendukung yang dekat dengan target utama yaitu remaja. Kecenderungan saat ini menunjukkan remaja lebih menyukai media yang mengandung hiburan.

\subsection{Konsep Digital Storytelling}

Pemilihan purwarupa komik interaktif yang merupakan gabungan dari komik dan multimedia didasarkan pada potensi kolaborasi aspek Relasi dan Tools dalam Digital Storytelling serta adaptasi model komunikasi SMCR. Berikut proses pengembangan konsep Digital Storytelling:

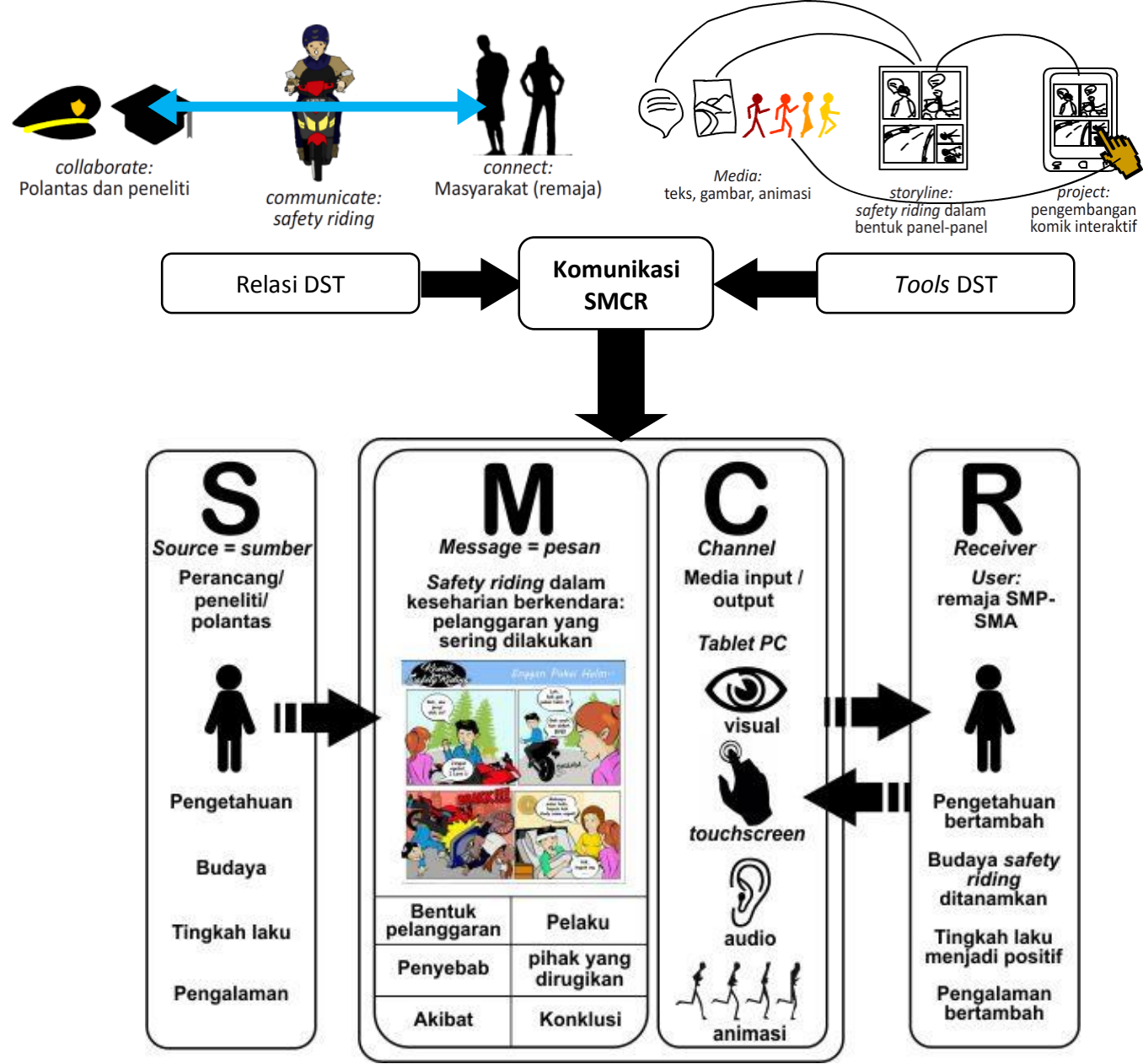

Gambar 5. Pengembangan Konsep Digital Storytelling

Pemetaan di atas menciptakan konsep DST secara lebih terperinci. Polantas dan peneliti menjadi Source dalam kampanye safety riding melalui pengetahuan, budaya, tingkah laku, serta pengalaman. Message kampanye tersebut dikemas dalam purwarupa komik interaktif menjadi poin-poin berupa: bentuk pelanggaran, penyebab, 
pelaku, pihak yang dirugikan, akibat, serta konklusi (kesimpulan). Channel yang digunakan source untuk menyampaikan pesan yakni Tablet PC, sebagai perangkat yang bisa diadaptasi untuk menjalankan komik interaktif. Remaja sebagai Receiver memanfaatkan indera untuk menangkap pesan kampanye safety riding. Setelah menerima pesan, Receiver diharapkan bisa menambah pengetahuan seputar safety riding, menanamkan budaya safety riding yang baik dan benar sehingga menciptakan tingkah laku positif serta menambah pengalaman dalam berkendara.

\subsection{Konsep Purwarupa Komik Interaktif}

Konsep purwarupa komik interaktif sebagai media pendukung kampanye safety riding akan memiliki dua mode tampilan, yaitu tampilan statis dan dinamis. Hal ini memberikan pengalaman yang berbeda kepada pembaca agar pesan yang disampaikan lebih mudah dipahami. Semakin menjamurnya perangkat digital yang ditawarkan kepada masyarakat juga menjadi nilai tambah bagi peneliti dalam mengembangkan konsep interaktif. Kehadiran perangkat tablet $P C$ yang bisa dioperasikan dengan touch serta memiliki bentang layar yang cukup luas (minimal 7 inch) cocok diadaptasi untuk menampilkan komik interaktif.

Sebagai acuan, peneliti mengadaptasi konsep aplikasi interaktif berjudul "Kisah Nabi Nuh" yang dibuat oleh Educa Studio. Konsep yang diadaptasi yaitu model interaktif pada objek-ojek dalam aplikasi tersebut akan bergerak ketika ditouch. Purwarupa komik interaktif menawarkan konsep tersebut namun bukan pada objeknya, tetapi pada tiap panel perhalaman, sehingga menciptakan media kampanye safety riding yang unik, interaktif, serta lebih mudah dipahami.

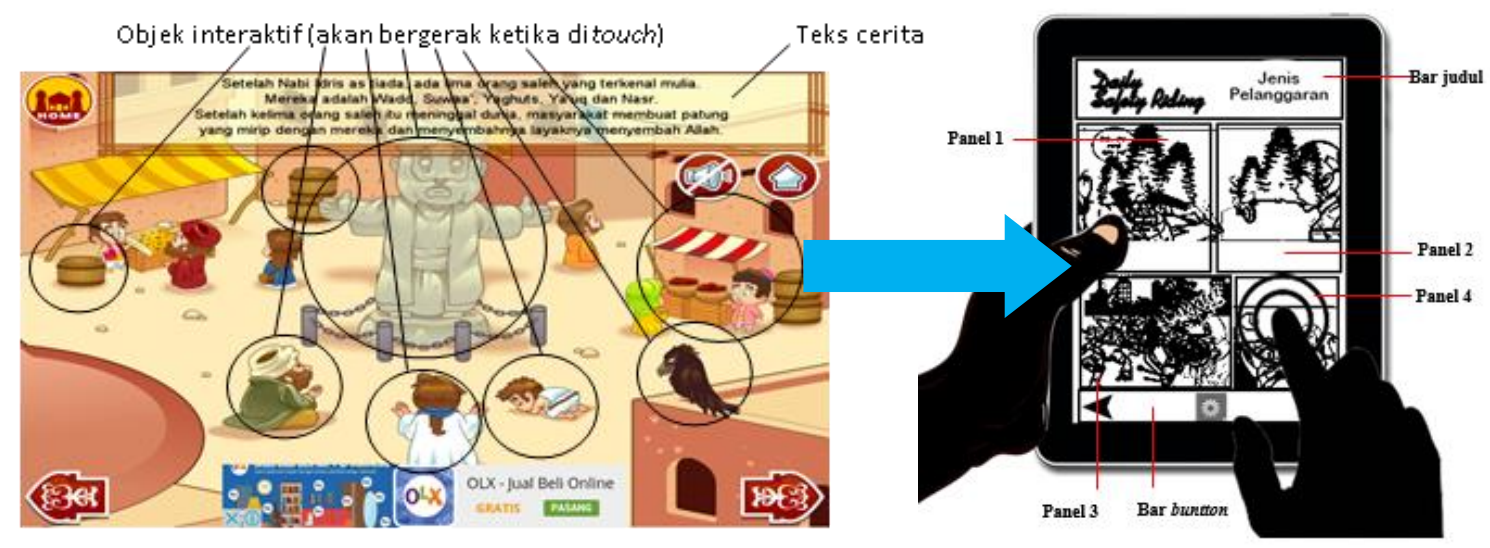

Gambar 6. Bahan referensi (kiri)

konsep purwarupa komik interaktif yang akan dikembangkan (kanan)

\subsection{Purwarupa Komik Interaktif Safety Riding}

Dengan berpedoman pada tabel 1 , topik safety riding yang akan digunakan sebagai konten purwarupa komik interaktif yaitu:1) akibat tidak memakai helm; 2)berkendara lewat trotoar karena macet; serta 3)melanggar lampu merah secara serentak. Purwarupa dibatasi tiga halaman sesuai dengan urutan topik tersebut. Pembatasan jumlah halaman ini didasarkan pada faktor trial and error, yang mana apabila berjalan lancar maka bisa dikembangkan lebih jauh, sedangkan jika mengalami kendala saat 
running setidaknya bisa dijadikan patokan sejauh mana pengembangan purwarupa komik interaktif bisa dilakukan.

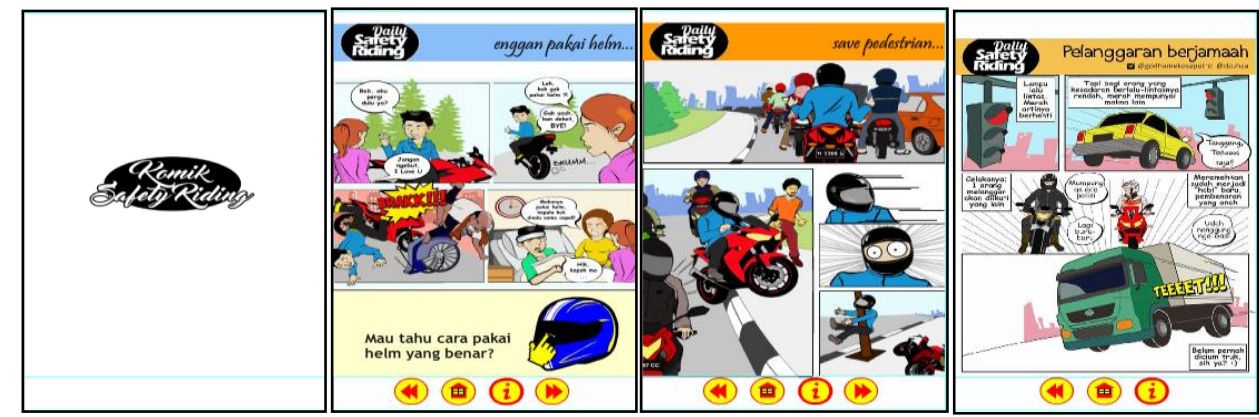

Gambar 7. Tampilan purwarupa komik interaktif safety riding Kiri ke kanan: Splashscreen, halaman 1, halaman 2, dan halaman 3

Purwarupa ini juga sudah bisa diimplementasikan pada perangkat tablet PC. Berikut tampilan ujicoba purwarupa komik interaktif safety riding:

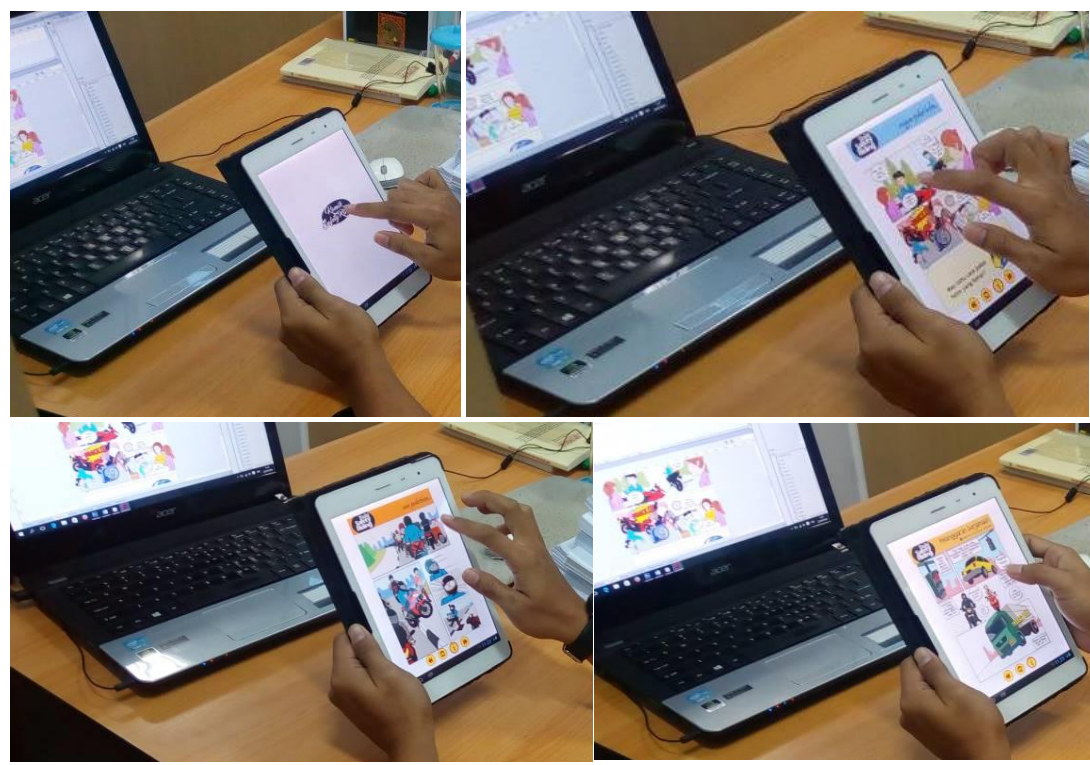

Gambar 8. Tampilan implementasi purwarupa komik interaktif safety riding pada perangkat tablet PC

\subsection{Perbandingan Purwarupa Komik Interaktif dengan Buku dan Game Safety Riding} Seperti yang telah dijelaskan bahwa sebelumnya peneliti pernah mengembangkan buku dan game sebagai media pendukung sosialisasi safety riding. Pengembangan purwarupa komik interaktif ini diharapkan bisa menutupi kekurangan dari kedua media tersebut. Dengan model komunikasi SMCR, tiap media yang pernah dikembangkan yakni dalam bentuk buku, game, dan purwarupa komik interaktif bisa dibandingkan sebagai pendukung bahwa pemilihan purwarupa komik interaktif sesuai dengan permasalahan yang ada. Berikut tabel berbandingan kegita media tersebut dengan konten yang sama yaitu sosialisasi safety riding. 
Tabel 2: Perbandingan media buku, game, dan purrwarupa komik interaktif dalam konteks safety riding

\begin{tabular}{|c|c|c|c|}
\hline Poin SMCR & Buku & Game & $\begin{array}{c}\text { Purwarupa komik } \\
\text { interaktif }\end{array}$ \\
\hline Source & Peneliti dan polantas & Peneliti dan polantas & Peneliti dan polantas \\
\hline Pengetahuan & $\begin{array}{l}\text { Lebih mudah didapatkan } \\
\text { dengan membaca }\end{array}$ & $\begin{array}{l}\text { Kurang mudah } \\
\text { didapatkan dengan } \\
\text { bermain game }\end{array}$ & $\begin{array}{l}\text { Mudah karena komik juga } \\
\text { butuh aktivitas membaca }\end{array}$ \\
\hline Budaya & $\begin{array}{l}\text { Membaca menjadi sarana } \\
\text { mendapatkan ilmu }\end{array}$ & $\begin{array}{l}\text { Bermain game menjadi } \\
\text { sarana hiburan, sehingga } \\
\text { aspek belajar berkurang }\end{array}$ & $\begin{array}{c}\text { Membaca komik selain } \\
\text { sebagai sarana hiburan } \\
\text { juga mengandung aspek } \\
\text { belajar }\end{array}$ \\
\hline Tingkah laku & Pasif, komunikasi 1 arah & Aktif, komunikasi 2 arah & Aktif, komunikasi 2 arah \\
\hline Pengalaman & $\begin{array}{c}\text { kurang berkesan karena } \\
\text { hanya membaca dan } \\
\text { bersifat monoton }\end{array}$ & $\begin{array}{l}\text { Berkesan karena hanya } \\
\text { belajar tetapi juga bisa } \\
\text { menikmati permainan }\end{array}$ & $\begin{array}{c}\text { Berkesan karena tidak } \\
\text { sekedar membaca tetapi } \\
\text { juga bisa menikmati } \\
\text { estetika visual }\end{array}$ \\
\hline Message & Safety riding & Safety riding & Safety riding \\
\hline Channel & $\begin{array}{c}\text { Buku } \\
\text { Teks+gambar } \rightarrow \text { mata }\end{array}$ & $\begin{array}{c}\text { Tablet pc } \\
\text { Gambar+animasi } \rightarrow \\
\text { mata, telinga, peraba }\end{array}$ & $\begin{array}{c}\text { Tablet pc } \\
\text { Teks+Gambar+animasi } \rightarrow \\
\text { mata dan peraba }\end{array}$ \\
\hline Receiver & $\begin{array}{l}\text { Kurang cocok untuk remaja } \\
\text { karena membutuhkan minat } \\
\text { baca tinggi }\end{array}$ & $\begin{array}{c}\text { Cocok untuk remaja } \\
\text { yang gemar bermain } \\
\text { game }\end{array}$ & $\begin{array}{c}\text { Cocok untuk remaja yang } \\
\text { hobi membaca komik }\end{array}$ \\
\hline
\end{tabular}

\section{PENUTUP}

\subsection{Kesimpulan}

Kampanye safety riding yang terus digalakkan oleh pihak kepolisian lalu lintas merupakan upaya yang sangat penting dilakukan. Hal ini didorong semakin banyaknya jumlah kendaraan bermotor yang lalu lalang di jalan raya, yang mulai tidak sebanding dengan luas jalan raya itu sendiri. Ditambah lagi, terjadinya kecelakaan yang disebabkan pengendara sepeda motor sangat memprihatinkan. Sebagai peneliti, merupakan tindakan yang tepat untuk mencoba memahami permasalahan ini dan membantu program kepolisian lalu lintas tersebut.

Hingga saat ini, kampanye safety riding dilakukan melalui talkshow ke sekolah-sekolah tingkat menengah, ditunjang dengan media spanduk dan leaflet. Selain itu juga disiarkan melalui stasiun radio. Namun, semakin pesatnya perkembangan teknologi saat ini yang salah satunya ditandai hadirnya perangkat mobile yang sangat bervariasi dari segi harga dan ukuran. Hal ini memberi peluang kepada peneliti untuk turut membantu program kampanye salah satunya yaitu melalui purwarupa komik interaktif safety riding. Konten dalam purwarupa komik interaktif ini bersumber dari kegiatan wawancara, observasi, dan studi literatur terkait pelanggaran lalu lintas. Terdapat tiga konten yang digunakan sebagai topik yaitu: tidak memakai helm, menyerobot lewat trotoar, serta melanggar lampu merah. Ketiga pelanggaran tersebut sering dilakukan, bahkan seolah menjadi perilaku berkendara yang dianggap wajar.

Melalui konsep digital storytelling, pengembangan purwarupa komik interaktif dibangun oleh beberapa elemen khususnya di tahapan komunikasi. Model komunikasi 
yang diadaptasi yaitu model SMCR, yang mana melibatkan source (polantas, peneliti), message (pelanggaran lalu lintas), channel (media dan indera), serta receiver (remajaSMA hingga mahasiswa). Dengan konsep ini, dihasilkan jabaran yang lebih rinci tentang konten purwarupa komik interaktif yang mengkombinasikan teks, gambar, serta animasi.

Purwarupa komik interaktif ini didesain menggunakan komputer tablet dengan sistem operasi android. Sistem operasi android dipilih karena sangat populer, terjangkau, dan didukung oleh fitur multimedia maksimal seperti layar sentuh sehingga para pengguna akan merasakan sensasi interaktif. Masyarakat tentunya akan lebih mudah dalam menerima serta mengetahui apabila media yang dipakai adalah media populer seperti tablet android yang memang dekat dengan mereka, mudah diunduh, dapat dibawa kemana-mana, serta dapat dimainkan setiap saat dimana saja. Implementasi purwarupa komik interaktif pada perangkat tablet PC juga menunjukkan bahwa hasil penelitian ini berpeluang untuk dikembangkan lebih lanjut sebagai upaya membantu program kepolisian lalu lintas dalam mengkampanyekan safety riding.

\subsection{Saran}

Intensnya kampanye safety riding yang dilaksanakan dengan baik oleh pihak kepolisian lalu lintas bisa menciptakan kolaborasi antara pihak terkait dengan akademisi atau praktisi. Hal ini bertujuan agar tercipta sarana kampanye yang tidak hanya fokus pada strategi yang telah dilakukan, tetapi juga mengeksplorasi media lain yang bisa diadaptasi untuk mendukung media yang telah ada. Salah satunya yaitu melalui purwarupa komik interaktif. Purwarupa komik interaktif yang mengangkat tema safety riding merupakan salah satu bentuk media baru, yang mana masih banyak lagi mediamedia lain yang belum tereksplorasi. Dengan demikian para peneliti diharapkan bisa memberikan sumbangsih baik berupa gagasan atau buah karya yang bisa memberikan manfaat khususnya dalam mengatasi masalah kurang tertibnnya pengendara dalam menerapkan safety riding, tentunya sesuai dengan bidang ilmu masing-masing.

\section{DAFTAR PUSTAKA}

Ariwibowo, R., 2013. Hubungan Antara Umur, Tingkat Pendidikan, Pengetahuan, Sikap Terhadap Praktik Safety Riding Awareness Pada Pengendara Ojek Sepeda Motor Di Kecamatan Banyumanik. Jurnal Kesehatan Masyarakat, 2 (1), p1-8

Binanto, I., 2010. Multimedia Digital - Dasar Teori dan Pengembangannya. Yogyakarta: ANDI

Boykhe, 2008. Yamaha Safety Riding Science (YSRS). Jakarta

Burnett, R., dkk., 2003. Perspective in Multimedia: Communication, Media, and Information Technology. England: Ojhn Wiley \& Sons, Ltd

CARRS-Q, 2012. State of The Road, a Fact Sheet of The Centre for Accidental Research \& Road Safety. Queensland

Danesi, M., 2010. Pengantar Memahami Semiotika Media. Yogyakarta: Jalasutra

DeNatale, G.M. (2008). Digital Storytelling: Tips and Resources. Boston: Simmon College

Depdikbud, 2008. Kamus Besar Bahasa Indonesia. Jakarta 
England, E., \& Finney, A., 2011. Interactive Media - What's that? Who's involved? (Updated:2011). URL: www.atsf.co.uk/atsf/interactive_media.pdf [diakses pada 27 April 2015]

Gay, L.R. 1990. Educational Evaluation and Measurement: Competencies for Analysis and Application. Second Edition. New York: Macmillan Publishing Company

McCloud, S., 2008. Understanding Comic. Jakarta: Gramedia

Mulyana, D. (2007). Ilmu Komunikasi Suatu Pengantar. Bandung: Rosdakarya

Parmikoadi, D., M., dkk., 2013. Transformasi Cara Penuturan Cerita dalam Bentuk Aplikasi Digital Storytelling sebagai Media Pengenalan Kembali Legenda "Calon Arang". Jurnal Nirmana, 15(1), p1-12

Pramitasari, Ratih, dkk, 2013. Perbedaan Perilaku Safety Riding (Keselamatan Berkendara) Berdasarkan Kepribadian Siswa SMA N 1 Semarang. (Updated: 2014).URL: eprints.dinus.ac.id/6615/1/jurnal_13179.pdf [diakses pada 27 April 2015]

Richey, J. D. K, Nelson, W. A. 2009. Developmental Research: Studies of Instructional Design and Development

Sindonews, 2013. 10 bulan, 839 Kasus Kecelakaan di Semarang. (Updated 20 November 2013) URL: http://daerah.sindonews.com/read/809146/22/10bulan-839-kasus kecelakaan-di-semarang-1385148691 [diakses pada 12 April 2014]

Sitompul, E. A., 2009. Gambaran Learned Helplessness pada Supir Angkutan di Medan Ditinjau dari Explanatory Style. Medan: Universitas Sumatera Utara

Sugiyono. 2009. Metode Penelitian Pendidikan Pendekatan Kuantitatif, Kualitatif, dan R \& D. Bandung : Alfabeta.

Tolisano, S.R. (2009). How To Guide Digital Storytelling Tools For Educators. Creative Commons

Undang-Undang Republik Indonesia Nomor 18 Tahun 2002 